\title{
Features of fire and explosion safety of buildings from a sandwich of panels
}

\author{
Eugenia Salymova ${ }^{1, *}$ \\ ${ }^{1}$ Moscow State University of Civil Engineering, Yaroslavskoe shosse, 26, Moscow, 129337, Russia
}

\begin{abstract}
Recently in Russia about $100 \%$ of buildings of an oil and gas complex are built with use triplex a sandwich of panels (S.P). Almost all these buildings are explosive and increase in their exploisure-resistance requires application of easily thrown off or safety designs. A sandwich of the panel is an ideal applicant for a role of safety designs according to the weight characteristics. Except inertial properties extremely important characteristic is opening pressure. This size remains acritical in view of a variety of their sizes, thickness of metal sheets, a variety of their fastening to metal designs. In work opening pressure at explosion for a sandwich of panels of $2 \times 1,2 \mathrm{~m}$ in size for various options of fastening is experimentally received. We suspect that load of one knot of fastening does not depend on the panel sizes, only on the knot device. For various ways of fastening design pressure of opening in case of a normal distribution of durability of clusters is defined. The criterion for assessment of effectiveness of the panels used as safety designs is received. This criterion determines the maximal pressure upon dive during opening. The received criterion confirms effectiveness a sandwich of panels as a safety design.
\end{abstract}

\section{Introduction}

A large number of the buildings and constructions with use a sandwich of panels have been built recently. Most often the sandwich of the panel is used at construction of warehouse and production rooms, and also offices, shops, supermarkets.

Most often buildings from panels are built at the enterprises of oil, gas and oil and gas branches. These buildings are at a fire risk. Our task is to find the ways to make them safe. We recommend applying easily thrown off or safety designs.

The easily thrown off designs is the most widespread a glazing, its effectiveness can change depending on the sizes, thickness, and also frequency rate of a glazing (unary, double or troyenny).

Triplex panels according to the weight characteristics can serve as efficient safety designs if to provide their reliable opening (destruction of fastenings) with pressure below admissible $(\Delta \mathrm{Pd})$. Admissible pressure is defined from conditions of inadmissibility of the collapses leading to loss of life and unacceptable material damage.

Indeterminacy of process of opening of the apertures blocked by panels does not allow using reasonably them as safety designs. The area of the easily thrown off designs and their

${ }^{*}$ Corresponding author: ICA_kbs@mgsu.ru 
characteristic are defined by calculations. However their carrying out it is impossible owing to obscurity of process of opening of safety designs from a sandwich of panels.

\section{Materials and Methods}

Change of pressure indoors at explosion. It is necessary to watch dynamics of change of pressure taking into account development of the center of explosion and the expiration of gases through apertures in the protecting designs. There is a speech about quasistatic development of process of the explosion caused by deflagration combustion of combustible gas system. Pressure at such explosion is identical in all points of the room and changes in time. Wave effects are absent. At flame propagations of $\mathrm{W}<30 \mathrm{~m} / \mathrm{s}$ explosion quasistatic. Many works as domestic and foreign experts are devoted to this problem [1-15].

The processes happening at internal explosion are represented by means of Figure 1.

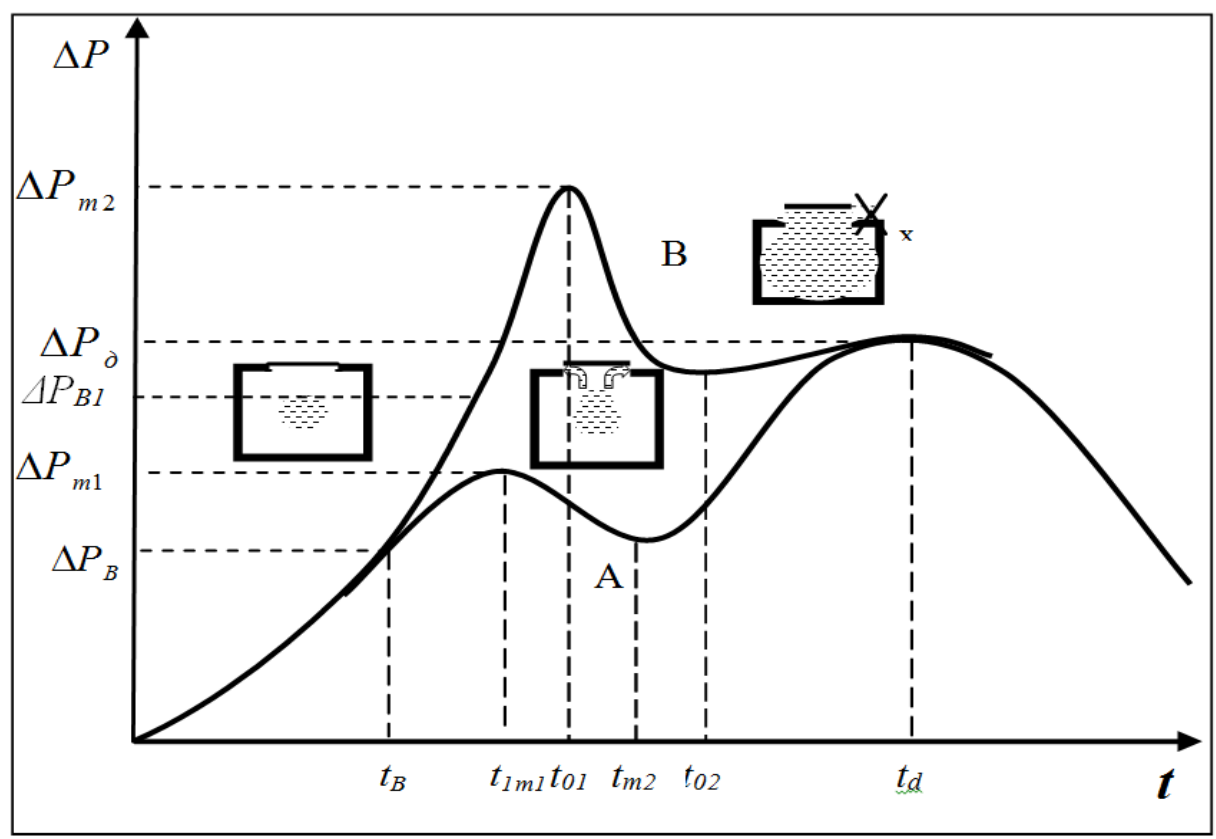

Fig. 1. The processes happening at internal explosion.

In an instant " 0 " there is an initiation and the flame extends in the form of the sphere in self contained volume (a shot 1). By the time of $\left\langle\mathrm{t}_{\mathrm{v}}\right\rangle$ time pressure reaches size $\Delta \mathrm{P}_{\mathrm{v}}-$ opening pressure. Safety designs start moving and gradually open space for the expiration of gases. At first cold gases expire, and then because of deformation of the combustion zone hot gases expire.

The quick-response safety design moves rather quickly and by the time of $\left\langle\mathrm{t}_{\mathrm{m} 1}\right\rangle$ time pressure reaches $\Delta \mathrm{P}_{\mathrm{m} 1}$ (a curve $\left.« \mathrm{~A} »\right)$.

More inertial safety designs the (a curve $\langle\mathrm{B} »)$ less aggressively opens an aperture for a depressurization and by the time of time $\Delta \mathrm{P}_{\mathrm{m} 2}>\Delta \mathrm{P}_{\mathrm{m} 1}$. To instants of $\left\langle\mathrm{t}_{01}\right\rangle$ and $\left\langle\mathrm{t}_{02}\right\rangle$ of armholes opened completely and pressure minima were implemented. The moments of « $\mathrm{t}_{01} »$ and $\left\langle\mathrm{t}_{02} »\right.$ are characterized by a condition: $\Pi \mathrm{X}=\mathrm{a} * \mathrm{~b}$, when the area of the expiration through lateral areas is compared to the area of an aperture, $\Pi$ - aperture perimeter, $X-$ the shift of the personal computer, « $\mathrm{a}^{*} \mathrm{~b}$ » - the area of an aperture. Since the moments of $\left\langle\mathrm{t}_{01}\right.$ » and « $\mathrm{t}_{02} »$ when the area of the expiration to become maximal, pressure begins to grow in 
system as the area of the center of explosion continues to grow at the invariable area of the expiration.

In « $\mathrm{t}_{\mathrm{d}}$ » instant burning area reaches a maximum, as determines pressure $\Delta \mathrm{P}_{\mathrm{d}}$ (admissible pressure). From explained above follows that the open space of apertures of $\left\langle\mathrm{S}_{0}\right\rangle$ by the time of time of $\left\langle\mathrm{t}_{\mathrm{d}}\right\rangle$ has to meet a condition:

$$
S_{0} \geq \frac{(\sigma-1) U_{g 2}{ }^{2} K_{f} V_{0}{ }^{2 / 3} \rho_{0}{ }^{1 / 2}\left[\xi+(1-\xi) \sigma^{1 / 2}\right]}{v_{g}\left(2 \Delta P_{g}\right)^{1 / 2}}
$$

Here $\mathrm{U}_{\mathrm{g} 2}$ - the speed of explosive combustion by the time of td, $\sigma$ - expansion ratio at combustion, $K_{f}=\frac{A_{f}}{V_{0}^{2 / 3}}$ - a crest factor of the room, $\left\langle\left\langle A_{f}\right\rangle-\right.$ the area of a flame by the time of $\left\langle\left\langle\mathrm{t}_{\mathrm{d}}\right\rangle, \Delta \mathrm{P}_{\mathrm{d}}-\right.$ the allowed pressure at explosion, $v_{\mathrm{g}}$ - a coefficient of discharge, $\mathrm{V}_{0}$ - room volume, $\xi$ - a share of the open space of apertures through which expires cold mix.

The allowed pressure at explosion is defined by calculation on a carrying capacity for the corresponding limiting condition. [15-19]. After definition of $\left\langle\mathrm{S}_{0} »\right.$ it is necessary to make so that at the time of opening of the easily thrown off designs pressure does not exceed $\Delta \mathrm{P}_{\mathrm{d}}$, that is the case $\Delta \mathrm{P}_{\mathrm{m} 2}>\Delta \mathrm{P}_{\mathrm{d}}$ (a curve $\langle\mathrm{B}\rangle$ fig. 1 ) does not provide a building explosion resistance. From Figure 1 it is visible that if $\Delta P_{v}$ on a curve "A» to increase opening pressure to $\Delta \mathrm{P}_{\mathrm{v} 1}$, then the condition of a explosion resistance is not satisfied also at quick-response by the easily thrown off designs. According to the weight characteristics, the sandwich panel is quick-response and can have easily thrown off designs if its reliable opening is provided. Reliable opening is characterized by a condition that at $\Delta \mathrm{P}_{\mathrm{v}}$ the opening peak $\Delta \mathrm{P}_{\mathrm{m}}$ is less $\Delta \mathrm{P}_{\mathrm{d}}$, and itself the easily thrown off designs at the same time is effective.

\section{Results}

Opening a panel sandwich at explosion. Analysis and experiment. The personal computer equation of motion after opening is described by the equation: $m_{P K} \frac{d^{2}}{d t^{2}}(X(t))=\Delta P(t) a b$, $\mathrm{m}_{\mathrm{pk}}$ - the mass of the easily thrown off designs, $\mathrm{X}(\mathrm{t})$ - the distance passed by the easily thrown off designs after opening, $\Delta \mathrm{P}(\mathrm{t})$ - the changing pressure upon the easily thrown off designs. In the analysis of an equation of motion we assume:

1. Only cold gases expire;

2. $\Delta P(t)=\frac{\Delta P_{v}+\Delta P_{m}}{2}=\Delta \bar{P}$

3. Overpressures at which outlet velocity of gases through apertures can be presented as are considered: $\sqrt{\frac{2 \Delta \bar{P}}{\rho_{0}}}$

The last assumption is accepted only for simplification. Pressure indoors during explosion taking into account the expiration of gases and shift of the personal computer has an appearance [20]:

$$
\frac{d \Delta P(t)}{d t}=\gamma(\sigma-1) \sigma^{2} 4 \pi U_{g} t^{2}-v_{g} \Pi X N\left(\frac{2 \Delta P(t)}{\rho_{0}}\right)^{1 / 2}
$$


From the assumptions made above and a condition $\frac{d \Delta P(t)}{d t}=0$, but $\Delta P(t)=\Delta P_{1}$ at the time of a maximum $\Delta \mathrm{P}(\mathrm{t})$ peak size $\Delta \mathrm{P}_{1}$ is determined.

$$
\begin{gathered}
\Delta P_{1}=\Delta P_{v} \frac{A}{\left(A^{1 / 2}-1\right)^{2}}, \\
A=\frac{v_{g}(a+b) a b \Delta P_{v}^{3 / 2} N}{2^{3 / 2} \pi m_{P K} \rho_{0}^{1 / 2} U_{g 1}{ }^{3}(\sigma-1) \sigma^{2}}
\end{gathered}
$$

Where $\mathrm{N}-$ number of the opened easily thrown off designs. $\mathrm{U}_{\mathrm{g} 1}-$ burning rate at the first peak, $\Pi=2(a+b)$.

Separately the opened safety designs are considered the safety designs which do not have the common borders. The having common borders are united in one safety designs. For $\Delta \mathrm{P}_{1}$ follows from the analysis of expression that $\Delta \mathrm{P}_{1}$ grows with body height $\Delta \mathrm{P}_{\mathrm{v}}$, but the relation $\Delta \mathrm{P}_{1} / \Delta \mathrm{P}_{\mathrm{v}}$ decreases with body height $\Delta \mathrm{P}_{\mathrm{V}}$.

Problem of the pilot study was assessment of tension failure load of fastening a sandwich of the panel and determination of pressure of opening a panel sandwich (P.S.) as safety designs.

The pilot study was conducted on the pilot units which main part was made by cameras of $10 \mathrm{~m}^{3}$ and $1 \mathrm{~m}^{3}$. For the whole SP fastening to the camera of $10 \mathrm{~m}^{3}$ the diffuser fastened. A narrow part of the diffuser fastened to an outlet opening of the camera, and to a wide part S.P. of $2 \times 1.2 \mathrm{~m}$ in size fastened.

Explosive cameras were equipped with system of ignition and filing of pressure. Disconnection of contacts on the diffuser and S.P. allowed fixing a start of motion (openings) of S.P. During experiences, high-speed video filming on which it was possible to duplicate the moment of opening was carried out and to control the movement safety designs. On the camera of $1 \mathrm{~m}^{3}$ S.P. of $0.4 \times 0.4 \mathrm{~m}$ in size fragments were tested. Details of carrying out experiments are explained in [21].

In the first series of experiments the joint ventures of $2 \times 1.2 \mathrm{~m}$ at nominal fastening were tested four self-tapping screws to a metal profile thickness $0.005 \mathrm{~m}$. In total 4 self-tapping screws were slightly deformed, but remained in a metal profile, having broken through S.P. a washer and a head of the self-tapping screw. Middle pressure of opening $\Delta \mathrm{P}_{\mathrm{v}}=3.34 \mathrm{kPa}$, $\sigma=0.06, \mathrm{~K}_{\mathrm{v}}=0.02$

The second series of experiences differed lack of washers under heads of self-tapping screws. In total 4 self-tapping screws were slightly deformed, but remained in a metal profile, having broken through a sandwich the panel a self-tapping screw head a leaf of S.P. Middle pressure of opening $\Delta \mathrm{P}_{\mathrm{v}}=2.18 \mathrm{kPa}, \sigma=0.088, \mathrm{~S}_{\mathrm{t}}=2.35, \mathrm{~K}_{\mathrm{v}}=0.04$.

In the third series of experiences in the sheet S.P. in the place of fastening under a washer cruciform cuts to border of washers became. In total 4 self-tapping screws were slightly deformed, but remained in a metal profile, having broken through a sandwich the panel a self-tapping screw head a leaf of S.P. Middle pressure of opening $\Delta \mathrm{P}_{\mathrm{v}}=1.28 \mathrm{kPa}$, $\sigma=0.11, S_{t}=2.35, K_{v}=0.086$.

The fourth series of experiments was conducted on the explosive camera $1 \mathrm{~m}^{3}$. Of $0.4 \times 0.4 \mathrm{~m}$ in size fragment of S.P. as the easily thrown off designs at nominal fastening was tested -2 self-tapping screws with washers to a metal profile $0.002 \mathrm{~m}$ thick. Destruction of fastenings came at the expense of a vyryv of self-tapping screws from a metal profile. Middle pressure of opening $\Delta \mathrm{P}_{\mathrm{v}}=15.16 \mathrm{kPa}, \sigma=0.18, \mathrm{~S}_{\mathrm{t}}=2.35, \mathrm{~K}_{\mathrm{v}}=0.12$.

More complete data including tension failure load on one self-tapping screw is presented in the Table 1 . 
Table 1. Results of the pilot study a sandwich panels, as easily thrown off designs.

\begin{tabular}{|c|c|c|c|c|c|c|c|}
\hline $\begin{array}{l}\text { No. of a } \\
\text { Series } \\
\text { of } \\
\text { experim } \\
\text { ents }\end{array}$ & $\begin{array}{l}\text { The tested } \\
\text { design }\end{array}$ & $\begin{array}{c}\text { Thickness } \\
\text { of a metal } \\
\text { profile, } \\
\text { mm }\end{array}$ & $\begin{array}{c}\text { Number } \\
\text { of self } \\
\text { tapping } \\
\text { screws }\end{array}$ & $\begin{array}{c}\text { Nature } \\
\text { of } \\
\text { destructi } \\
\text { on }\end{array}$ & $\begin{array}{c}\text { Pressure } \\
\text { of } \\
\text { opening, } \\
\mathrm{kPa} \text {. }\end{array}$ & $\begin{array}{l}\text { Load of } \\
\text { one self- } \\
\text { tapping } \\
\text { screw, } \\
\text { kN }\end{array}$ & Note \\
\hline 1 & $\begin{array}{l}\text { sandwich } \\
\text { panels, } \\
1200 \times 2000 \mathrm{x} \\
50 \mathrm{~mm}\end{array}$ & 5 & 4 & $\begin{array}{l}\text { The self } \\
\text { tapping } \\
\text { screw in } \\
\text { a metal } \\
\text { profile }\end{array}$ & $\begin{array}{c}3,2 \\
3,38 \\
3,45\end{array}$ & $\begin{array}{l}1,92 \\
2,03 \\
2,07\end{array}$ & - \\
\hline 2 & $\begin{array}{c}\text { sandwich } \\
\text { panels, } \\
1200 \times 2000 \mathrm{x} \\
50 \mathrm{~mm}\end{array}$ & 5 & 4 & $\begin{array}{l}\text { The self } \\
\text { tapping } \\
\text { screw in } \\
\text { a metal } \\
\text { profile }\end{array}$ & $\begin{array}{c}2,4 \\
2,03 \\
2,2\end{array}$ & $\begin{array}{l}1,44 \\
1,20 \\
1,32\end{array}$ & $\begin{array}{l}\text { Without } \\
\text { washers }\end{array}$ \\
\hline 3 & $\begin{array}{c}\text { sandwich } \\
\text { panels } \\
1200 \times 2000 \mathrm{x} \\
50 \mathrm{~mm}\end{array}$ & 5 & 4 & $\begin{array}{l}\text { The self } \\
\text { tapping } \\
\text { screw in } \\
\text { a metal } \\
\text { profile }\end{array}$ & $\begin{array}{c}1,2 \\
1,55 \\
1,1\end{array}$ & $\begin{array}{l}0,72 \\
0,93 \\
0,66\end{array}$ & $\begin{array}{c}\text { Cut of a } \\
\text { metal } \\
\text { leaf }\end{array}$ \\
\hline 4 & $\begin{array}{c}\text { Fragment } \\
\text { panel } \\
\text { sandwich,40 } \\
0 \times 400 \times 50 \\
\text { mm }\end{array}$ & 2 & 2 & $\begin{array}{l}\text { The self- } \\
\text { tapping } \\
\text { screw in } \\
\text { the panel }\end{array}$ & $\begin{array}{c}11,28 \\
18,8 \\
15,40\end{array}$ & $\begin{array}{l}0,90 \\
1,50 \\
1,23\end{array}$ & \begin{tabular}{|c|} 
Thickn \\
ess of \\
a \\
design \\
is 2 \\
$\mathrm{~mm}$ \\
\end{tabular} \\
\hline
\end{tabular}

The necessary number of self-tapping screws used at nominal fastening depends from S.P. In to the Table 2 are long the nominal number of self-tapping screws and recommended for S.P. used as the easily thrown off designs for opening pressure decrease is specified. Self-tapping screws fasten with washers and destruction of fastening happens on the mechanism of break of a leaf (the first series of experiments).

Table 2. Dependence of pressure of opening on a way of fastening of safety designs.

\begin{tabular}{|c|c|c|c|c|c|}
\hline $\begin{array}{c}\text { Length } \\
\text { of the } \\
\text { panel, } \\
\mathrm{m}\end{array}$ & $\begin{array}{c}\text { Number of } \\
\text { self- } \\
\text { tapping } \\
\text { screws }\end{array}$ & $\begin{array}{c}\text { Pressure } \\
\text { of } \\
\text { opening, } \\
\mathrm{kPa}\end{array}$ & $\begin{array}{c}\text { The } \\
\text { recommended } \\
\text { number of self- } \\
\text { tapping screws }\end{array}$ & $\begin{array}{c}\text { Middle pressure of } \\
\text { opening, at the } \\
\text { recommended } \\
\text { fastening of self- } \\
\text { tapping screws, kPa }\end{array}$ & $\begin{array}{c}\text { The } \\
\text { recommended } \\
\text { pressure of } \\
\text { opening, } \mathrm{kPa}\end{array}$ \\
\hline 2 & 4 & 3.34 & $\begin{array}{c}4 \text { Without } \\
\text { washers }\end{array}$ & 2.18 & 3.1 \\
\hline 2 & 4 & 3.34 & $\begin{array}{c}4 \text { Cut of a metal } \\
\text { leaf }\end{array}$ & 1.28 & 2.0 \\
\hline 3 & 6 & 3.34 & 4 nominal & 2.23 & 3.0 \\
\hline 3 & 6 & 3.34 & $\begin{array}{c}4 \text { Without } \\
\text { washers }\end{array}$ & 1.45 & 2.24 \\
\hline 4.5 & 8 & 3 & 4 nominal & 2.25 & 1.6 \\
\hline 4.5 & 8 & 3 & $\begin{array}{c}4 \text { Without } \\
\text { washers }\end{array}$ & 1.45 & 1.63 \\
\hline 6 & 10 & 2.8 & 4 nominal & 2.24 & 2.3 \\
\hline 6 & 10 & 2.8 & 6 nominal & 1.7 & 2.1 \\
\hline
\end{tabular}


At construction Table 2 it was supposed that average load of 1 screw remains for the corresponding way of fastening.

Assuming that distribution of destructive deformations submits to the normal law to distribution, it turns out the following design pressure of opening (last table column 2). At the same time reliability of opening more than $99 \%$ is provided. In to the Table 2 data on design pressure of opening for various options of fastening of the safety designs.

\section{Discussion}

Design of the safety designs and determination of the area of the safety designs. At installation a sandwich of the panel fasten screws to metal designs. Besides for ensuring safety designs of the panel connect to a solid heater among themselves the "ledge-a groove" system. Such padding communication between panels complicates opening of the safety designs therefore individual panels will be opened with a larger pressure, than in experiments where the panel fastened without the side system "ledge-a groove". For elimination and minimizing of influence of communication between panels when opening, it is offered:

1. To unite panels with the weakened fastenings in one card consisting of several panels so that at edges of the panel there was no communication "a ledge - a groove";

2. To delete ledges, and to fill grooves with the weak sealants;

3. As the safety designs to use panels with the weak heater (a mineral wool and so on) which connection among themselves has no communication "a ledge - a groove";

4. As the safety designs to use panels with minimum thickness of metal sheet of $0,5 \mathrm{~mm}$;

5. To reduce designs for fastening of the panels used as the safety designs to thickness of 2 $\mathrm{mm}$ in the place of fastening.

For the determination of the area of the safety designs, it is necessary to determine first of all the size of the allowed pressure $\Delta \mathrm{P}_{\mathrm{d}}$. As a rule, the allowed pressure is defined by calculation on a carrying capacity for the first group of the limiting conditions [19]. About use of the equivalent statistical loading [19,22]. Further on expression (1) to be the required area of open apertures. The sizes of cards get out of design reasons. The card consists of safety designs, which are in contact with each other. It is necessary to remember that the safety design is a sandwich panel with the weakened fastening. Let «a»- length of the safety designs, «b» - safety design width, $\mathrm{b}=1.2 \mathrm{~m}$ is routine.

The area of the card is equal: $S_{k}=a^{*} b^{*} n$ where $\mathrm{n}$ - number of panels in the card.

The number of cards is equal: $N=S_{0} / S_{k}$

This «N» value should be substituted in expression (2-3), and instead of $(a * b)$ it is necessary to substitute $S_{k}$, instead of $(a+b) \rightarrow(a+n * b)$, pressure of opening undertakes calculated.

Further on expressions (3) the condition $\Delta \mathrm{P}_{1}$ is checked $\Delta \mathrm{P}_{1}<\Delta \mathrm{P}_{\mathrm{d}}$. If this condition is satisfied, then calculation comes to an end. If it is not carried out, then it is possible to take also measures: 1 - to increase $S_{0}, 2$ - to reduce design pressure of opening, 3 - to increase number of cards.

\section{Conclusion}

According to the weight characteristics, a sandwich of the panel is an ideal safety designs. It is necessary to weaken fastening clusters to designs to make them safe.

It is possible to provide stability not only for load-bearing frames, but also for sandwich of panels, which are used as the protecting designs. It is necessary to use as the 
protecting designs smaller panels with the larger thickness of a leaf, in comparison with safety designs which fastening is weakened.

For example, when using as safety designs the $6^{\text {th }}$ meter panels with fastening -4 nominal self-tapping screws, it is possible to provide protection of less than $50 \%$ of the protecting designs from panels whose values in the Table 3 are highlighted in red color; from $50 \%$ and to $100 \%$ - black and $100 \%$ - green.

Table 3. Dependence of change of reliability a panel sandwich from its sizes.

\begin{tabular}{|c|c|c|c|c|c|c|c|c|c|c|c|c|c|c|}
\hline \multirow{3}{*}{$\begin{array}{l}\text { Thickne } \\
\text { ss of the } \\
\text { panel, } \\
\text { mm }\end{array}$} & \multicolumn{14}{|c|}{ Carrying capacity of panels at evenly distributed load, $\mathrm{kg} / \mathrm{m}^{2}$} \\
\hline & \multicolumn{14}{|c|}{ Length of flight, $\mathrm{m}$} \\
\hline & 1.5 & 2.0 & 2.5 & 3.0 & 3.5 & 4.0 & 4.5 & 5.0 & 5.5 & 6.0 & 6.5 & 7.0 & $\begin{array}{l}8 . \\
0\end{array}$ & $\begin{array}{l}9 . \\
0\end{array}$ \\
\hline 60 & $\begin{array}{l}18 \\
0\end{array}$ & $\begin{array}{l}13 \\
5\end{array}$ & $\begin{array}{l}10 \\
5\end{array}$ & 85 & 70 & 50 & 30 & & & & & & & \\
\hline 100 & $\begin{array}{l}33 \\
6\end{array}$ & $\begin{array}{l}24 \\
6\end{array}$ & $\begin{array}{l}19 \\
8\end{array}$ & $\begin{array}{l}16 \\
5\end{array}$ & $\begin{array}{l}14 \\
2\end{array}$ & $\begin{array}{l}12 \\
8\end{array}$ & $\begin{array}{l}11 \\
0\end{array}$ & 90 & 75 & 60 & 48 & 38 & 27 & \\
\hline 120 & & $\begin{array}{l}34 \\
0\end{array}$ & $\begin{array}{l}23 \\
8\end{array}$ & $\begin{array}{l}19 \\
6\end{array}$ & $\begin{array}{l}17 \\
0\end{array}$ & $\begin{array}{l}15 \\
2\end{array}$ & $\begin{array}{l}13 \\
0\end{array}$ & $\begin{array}{l}11 \\
0\end{array}$ & 90 & 78 & 68 & 56 & 40 & 28 \\
\hline 150 & & & $\begin{array}{l}32 \\
5\end{array}$ & $\begin{array}{l}25 \\
5 \\
\end{array}$ & $\begin{array}{l}21 \\
2\end{array}$ & $\begin{array}{l}18 \\
5\end{array}$ & $\begin{array}{l}16 \\
8 \\
\end{array}$ & $\begin{array}{l}14 \\
5\end{array}$ & $\begin{array}{l}10 \\
8 \\
\end{array}$ & 98 & 84 & 70 & 50 & 35 \\
\hline 200 & & & & $\begin{array}{l}34 \\
0\end{array}$ & $\begin{array}{l}38 \\
6\end{array}$ & $\begin{array}{l}25 \\
0 \\
\end{array}$ & $\begin{array}{l}21 \\
2 \\
\end{array}$ & $\begin{array}{l}19 \\
0\end{array}$ & $\begin{array}{l}15 \\
2\end{array}$ & $\begin{array}{l}12 \\
2\end{array}$ & $\begin{array}{l}10 \\
5\end{array}$ & 90 & 68 & 52 \\
\hline 250 & & & & & $\begin{array}{l}37 \\
0\end{array}$ & $\begin{array}{l}31 \\
5\end{array}$ & $\begin{array}{l}27 \\
0\end{array}$ & $\begin{array}{l}22 \\
9\end{array}$ & $\begin{array}{l}18 \\
6\end{array}$ & $\begin{array}{l}15 \\
0\end{array}$ & $\begin{array}{l}12 \\
8\end{array}$ & $\begin{array}{l}11 \\
0\end{array}$ & 82 & 65 \\
\hline
\end{tabular}

\section{References}

1. V. S. Babkin, Physics of combustion and explosion 5, 14-19 (2006)

2. V.S. Babkin, P.K. Senachin, T.V. Krakhtinova, Physics of combustion and explosion 6, $14-20$ (1982)

3. J.B. Bell, Western States Section of the Combustion Institute, 29-30 (2004)

4. D. Bradly, A. Mitcheson, Comb.Flame 32, 221 - 236 (1978)

5. D. Bradly, A. Mitcheson, Comb.Flame 32, 237 (1978)

6. C. Chan, I.O. Moen, Y.H.S. Lee, Comb. Flame 49, 27 - 39 (1983)

7. V.A Gorev, V.N. Fedotov, About a role of acoustic vibrations at explosive combustion of gases in the depressurized vessel (Academy of Sciences of the USSR, Novosibirsk, 1988)

8. S.B. Dorofeev, A.V. Bezmelnitsin, V.P. Sidorov, Air Explosions Comb. and Flame 103, 243 (1995)

9. H.G. Im, Twenty-Eighth International Symposium on Combustion. Edinburgh (2000)

10. V.A. Kotlyarevsky, I.M. Raynin, Structural mechanics and calculation of constructions 5, $52-56(1990)$

11. R.K. Kumar, W.A Dewit, D.R. Greig, Combustion Scienceand Technology 66, 251 266 (1989)

12. D.V. Makarov, Physicist of combustion and explosion 40(2), 13 - 23 (2004)

13. I.O. Moen, M. Donato, Progressin Astronomyand Aeronautics 75, 33 - 47(1981)

14. I.O. Moen, Y.H.S Lee, B.H. Hjertager, K. Fuhre, R. Eckhoff, Large Scale Methane Air Explosions of Raufoss (Norway, 1980) 
15. L.P. Pilyugin, Providing a safety of buildings by means of safety designs (Fire Safety and Science association, 2000)

16. L.P. Pilyugin, Prediction of consequences of internal emergency explosions (Stroyizdat, Moscow, 2010)

17. G.I. Priests, Reinforced concrete designs subject to action of pulse loadings (Stroyizdat, Moscow, 1986)

18. N.N. Priests, B.S. Rastorguyev, Questions of calculation and constructioning of express constructions (Stroyizdat, Moscow, 1980)

19. N.N. Priests, B.S. Rastorguyev, Dynamic calculation of reinforced concrete designs (Stroyizdat, Moscow, 1974)

20. H. Ryuzaki, R. Tominaga, International Gas Union Research Conference, 15 (2011)

21. Ye.Yu. Salymova, Dynamics of development of dangerous factors in buildings with enclosing structures made of sandwich panels in fires and explosions (Moscow State University of Civil Engineering, Moscow, 2015)

22. D. Korolchenko, A. Tusnin, S. Trushin, A. Korolchenko, International Journal of Applied Engineering Research 10(21), 42541-42548 (2015) 